\title{
A PARTILHA DO SOFRIMENTO: RELACÕES INSTRUMENTAIS ENTRE ANIMAIS DE LABORATÓRIO E SUA GENTE*
}

\author{
Donna Haraway \\ University of California at Santa Cruz - Estados Unidos
}

\begin{abstract}
Resumo: É importante que as "condições compartilhadas de trabalho" em um laboratório experimental nos façam entender que as entidades com limites totalmente seguros chamadas indivíduos possessivos (imaginados como humanos ou animais) são as unidades erradas para considerar o que está acontecendo. Isso significa não que um determinado animal não importa, mas que o importar está sempre dentro de conexões que exigem e possibilitam resposta, não classificação ou calculação nua e crua. Neste artigo, ao colocar em diálogo personagens reais com personagens ficcionais, filósofos com biólogos, proponho repensar as relações instrumentais entre animais de laboratório e sua gente, centrando esforços no trabalho epistemológico, emocional, e técnico necessário para práticas de cuidado e de partilha não mimética. Argumento que a moralidade necessária para o florescimento multiespécies vai além de hierarquias taxonômicas, filosofias humanistas ou garantias religiosas. Exige uma forte sensibilidade não antropomórfica atenta a diferenças irredutiveis.
\end{abstract}

Palavras-chave: antropologia da ciência, espécies companheiras, ética de pesquisa, experimentação animal.

Abstract: It is important that the "shared conditions of work" in an experimental lab make us understand that entities with fully secured boundaries called possessive individuals are the wrong units for considering what is going on. That means not that a particular animal does not matter but that mattering is always inside connections that demand and enable response, not bare calculation or ranking. In this article, by bringing into dialogue fictional with real-life characters, philosophers with biologists, we propose to rethink the instrumental relations between laboratory animals and their people, centering on the epistemological, emotional, and technical work necessary for practices of care and non-mimetic sharing. I argue that the needed

* Este texto, que apareceu originalmente como o capítulo 3 de When species meet (Haraway, 2008), é publicado com a permissão da University of Minnesota Press.

Horizontes Antropológicos, Porto Alegre, ano 17, n. 35, p. 27-64, jan./jun. 2011 
morality for a multispecies flourishing goes beyond taxonomic hierarchies, humanist philosophies or religious guarantees. It requires a robust nonanthropomorphic sensibility that is accountable to irreducible differences.

Keywords: animal experiments, anthropology of science, companion species, research ethics.

Quando li o romance de Nancy Farmer (1996) para jovens adultos Uma menina chamada Desastre, fiquei fascinada pela história do relacionamento entre um velho vapostori africano e os porquinhos-da-índia cuidados por ele numa pequena estação científica no Zimbábue por volta de 1980. Os roedores do laboratório, usados para pesquisa da doença do sono, estavam no centro de um nó juntando moscas-tsé-tsés, tripanosomas, gado e gente. Durante o seu horário de trabalho, os porquinhos-da-índia eram mantidos em cestinhos apertados enquanto gaiolas de tela cheias de moscas picadoras eram colocadas sobre eles, que tinham tido a pele raspada e pintada com venenos que podiam afetar os insetos ofensores com seus parasitos protozoários. As moscas se empanturravam com o sangue dos porquinhos-da-índia. Uma menina xona adolescente, Nhamo, nova nas práticas da ciência, observava.

"É cruel”, Baba Joseph concordou, "mas um dia as coisas que aprendemos vão evitar que o nosso gado morra". Ele enfiou o próprio braço dentro da gaiola de tsé-tsés. Nhamo tampou a boca para não gritar. As moscas pousaram por toda a pele do velho e começaram a chupar. "Eu faço isso para saber o que os porquinhos-da-índia estão sofrendo", ele explicou. "Causar dor é maldade, mas se eu a compartilho pode ser que Deus me perdoe." (Farmer, 1996, p. 239). ${ }^{1}$

Parece-me que Baba Joseph oferece uma visão profunda de como pensar o trabalho dos animais e sua gente nas práticas científicas, especialmente nos laboratórios experimentais. A ciência animal experimental tratada neste

\footnotetext{
1 Os vapostoris rejeitam qualquer tipo de tratamento médico para si mesmos, sendo adeptos de uma igreja cristã africana independente fundada em 1932 por Johane Maranke. Em 2006, afora outros mamíferos, entre 300 mil e 500 mil pessoas na África subsaariana estavam infectadas com a doença do sono, e cerca de 40 mil seres humanos morrem todos os anos. A epidemia atual data de 1970, depois que a triagem e a vigilância eficaz contra os surtos anteriores foram negligenciadas. Ver http://en.wikipedia.org/wiki/ Sleeping_sickness.
}

Horizontes Antropológicos, Porto Alegre, ano 17, n. 35, p. 27-64, jan./jun. 2011 
artigo consiste em grande parte de pesquisa médica e veterinária na qual os animais têm doenças de interesse das pessoas. Grande parte da ciência animal experimental não é desse tipo e, em minha opinião, a pesquisa biológica mais interessante, dentro e fora dos laboratórios, não está muito preocupada com a espécie humana. A noção de que "o estudo correto do homem é a humanidade" é risível entre a maioria dos biólogos que conheço, cuja curiosidade gira, na verdade, em torno de outras criaturas. A curiosidade, não apenas o benefício funcional, pode valer o risco da "ação malvada". Baba Joseph, no entanto, está preocupado com o gado doente, com os porquinhos-da-índia coagidos e com a gente deles.

O cuidador de animais não está envolvido em atos heroicos de autoexperimentação (uma coisa comum nas histórias de medicina tropical) (Herzig, 2005), mas sim na obrigação prática e moral de mitigar o sofrimento entre os mortais - e não apenas humanos mortais - sempre que possível e compartilhar as condições de trabalho, inclusive o sofrimento, dos atores mais vulneráveis do laboratório. O braço picado de Baba Joseph não é o fruto de uma fantasia heroica de extinguir todo sofrimento ou não causar sofrimento, mas o resultado de assumir o risco e a solidariedade implicados nos relacionamentos instrumentais em vez de negá-los. Usar um organismo-modelo numa experiência é uma necessidade comum em pesquisa. A necessidade e as justificativas, por mais forte que sejam, não diminuem as obrigações do cuidado e do compartilhamento da dor. De que outra forma a necessidade e a justiça (justificativa) poderiam ser avaliadas em um mundo mortal no qual a aquisição de conhecimento nunca é inocente? Há, evidentemente, outros parâmetros de avaliação além deste, mas esquecer do critério de partilhar a dor para saber o que é o sofrimento dos animais e o que fazer a respeito disso não é mais tolerável, se é que o foi algum dia.

\section{Compartilhamento e resposta}

É importante que as "condições compartilhadas de trabalho" em um laboratório experimental nos façam entender que as entidades com limites totalmente seguros chamadas indivíduos possessivos (imaginados como humanos ou animais) são as unidades erradas para considerar o que está acontecendo. ${ }^{2}$

2 A exposição clássica é C. B. Macpherson (1962). 
Isso significa não que um determinado animal não importa, mas que o importar está sempre dentro de conexões que exigem e possibilitam resposta, não classificação ou calculação nua e crua. A resposta, é claro, cresce com a capacidade de responder, ou seja, responsabilidade. Tal capacidade pode ser moldada apenas em e para relacionamentos multidirecionais, nos quais sempre mais de um ente responsivo está em processo de vir a ser. Isso significa que os seres humanos não são os únicos devedores e dotados de responsabilidade. Animais, como trabalhadores em laboratórios, animais em todos os seus mundos são responsáveis, ou capazes de resposta, no mesmo sentido em que as pessoas o são. Isto é, a responsabilidade é um relacionamento construído em intra-ação através do qual os entes, sujeitos e objetos, passam a existir. ${ }^{3}$ As pessoas e os animais em laboratórios são, ao mesmo tempo, sujeitos e objetos uns dos outros na intraação em andamento. Se essa estrutura de relação material-semiótica é rompida ou impedida de nascer, então nada mais resta além de objetificação e opressão. As partes em intra-ação não admitem cálculos taxonômicos preestabelecidos; os próprios respondentes são coconstituídos no ato de responder e não dispõem com antecedência de uma lista de checagem de propriedades. Além disso, não se espera que a capacidade de responder e, portanto, de ser responsável, tome formas e texturas simétricas para todas as partes. A resposta não pode emergir dentro de relacionamentos de autossimilaridade.

O cálculo, tal como uma comparação de risco-benefício medida por classificação taxonômica, é suficiente dentro de relações de autossimilaridade delimitada, tal como o humanismo e sua consequência. Por não depender de uma lista de checagem, a resposta é sempre algo mais perigoso. Se um laboratório experimental torna-se palco de apenas cálculo em relação a animais ou pessoas, esse laboratório deve ser fechado. Minimizar a crueldade, embora seja necessário, não basta; a responsabilidade exige mais do que isso. Estou afirmando que as relações instrumentais de pessoas e animais não são por si só a raiz da transformação de animais (ou pessoas) em coisas mortas, em máquinas cujas reações interessam, mas não têm nenhuma presença, nenhuma face, que exija reconhecimento, cuidado e dor compartilhada. A própria intra-ação instrumental não é o inimigo; na verdade, vou argumentar abaixo que o trabalho, o uso e a instrumentalidade são intrínsecos ao ser e ao devir mortal terreno

\footnotetext{
3 Karen Barad (2007) construiu ao longo de muitos anos e em muitas publicações a poderosa teoria feminista de intra-ação e realismo agencial. Ela e eu afirmamos solidária e firmemente que essa teoria se aplica com muita propriedade aos animais enredados em relações de prática científica.
}

Horizontes Antropológicos, Porto Alegre, ano 17, n. 35, p. 27-64, jan./jun. 2011 
e corporalmente enredado. As relações unidirecionais de uso, reguladas por práticas de cálculo e convencidas da razão hierárquica, são outros quinhentos. Tais cálculos complacentes se inspiram no dualismo primário que separa de um lado o corpo, de outro lado a mente. Esse dualismo deveria ter acabado há muito tempo diante das críticas feministas e tantas outras, mas o fantástico sistema binário mente/corpo demonstrou uma notável resiliência. Creio que a incapacidade, ou melhor, a recusa de encarar os animais é uma das razões.

Estamos no meio de existências conectadas, múltiplos seres em relacionamento, aqui um animal, ali uma criança doente, uma aldeia, rebanhos, laboratórios, bairros numa cidade, indústrias e economias, ecologias que ligam naturezas e culturas sem fim. É uma tapeçaria de ser/devir compartilhada e que se ramifica entre criaturas (inclusive humanas) na qual viver bem, desabrochar e ser "educado" (político, ético, corretamente relacionado) significa permanecer dentro de uma materialidade semiótica compartilhada, que inclui o sofrimento inerente em relacionamentos instrumentais ontologicamente múltiplos e desiguais. Nesse sentido, a pesquisa animal experimental é, ou pode ser, necessária, até mesmo boa, mas não pode nunca "legitimar" uma relação com o sofrimento de maneira puramente regulamentar ou descomprometida e insensível. Vem então a pergunta interessante: com que pareceria um "compartilhamento de sofrimento" responsável em práticas historicamente situadas?

O sentido de partilha sobre o qual estou tentando pensar é tão epistemológico quanto prático. ${ }^{4}$ Não se trata nem de substituir o substituto nem de ocupar o lugar do "outro" que sofre e que precisamos considerar. Não temos

\footnotetext{
${ }^{4}$ Minha ideia sobre o que a partilha de sofrimento pode significar foi desenvolvida em parte em um longo diálogo por e-mail em julho de 2006 com Thom van Dooren, um acadêmico e escritor australiano que trata dos mundos das sementes na agricultura tecnocientífica. Em 3 de julho de 2006, van Dooren me escreveu: "Certo sofrimento parece beneficiar apenas grupos muito específicos de maneiras muito superficiais. Para ver como tudo isso acontece, é necessário que nós habitemos os tipos de espaços compartilhados a que você se refere. Mas isso tudo é 'partilha epistemológica', e não faço ideia de como podemos compartilhar de forma mais concreta, caótica e, me parece, significativa. Isso também é importante, penso eu, para chegar até o que está acontecendo nos relacionamentos humanos globais nos quais todos nós estamos indiscutivelmente envolvidos no sofrimento de inumeráveis humanos (por exemplo, na maneira como nossos estilos de vida são possibilitados pelos deles) e também nos criatórios industriais. Essas 'criaturas' (para usar mais um dos seus termos) todas sofrem por nós também - de uma maneira ou de outra. Como podemos de fato habitar um espaço compartilhado de sofrimento com elas, e com qual finalidade? Especialmente quando tanto desse sofrimento parece completamente injustificado e evitável. Em suma, não sei se estou entendendo bem [...]. Não estou certo de o que solidariedade e partilha poderiam ser a menos que eu queira me colocar no lugar delas. O que levanta um monte de outras questões sobre por que não posso trocar de lugar com elas, por que, por exemplo, 'permite-se' que algumas criaturas (até alguns humanos) sofram e outras não."
}

Horizontes Antropológicos, Porto Alegre, ano 17, n. 35, p. 27-64, jan./jun. 2011 
necessidade de nenhuma versão nova-era da falsa e banal afirmação "eu sinto a sua dor". Algumas vezes, talvez, "tomar o lugar da vítima" seja um tipo de ação eticamente exigido, mas não acho que isso seja partilha e, além disso, aqueles que sofrem, inclusive animais, não são necessariamente vítimas. $\mathrm{O}$ que acontece se não consideramos ou tratamos animais de laboratório como vítimas, ou como outros em relação ao humano, ou vemos seu sofrimento e suas mortes como sacrifício? O que acontece se os animais experimentais não são substitutos mecânicos, mas parceiros significantemente não livres, cujas diferenças e semelhanças com os seres humanos, uns com os outros, e com outros organismos são cruciais para o trabalho do laboratório e, na verdade, são parcialmente construídos pelo trabalho do laboratório? O que acontece se os animais de trabalho são outros significantes com quem estamos em relacionamento de consequência em um mundo irredutível de diferenças parciais vividas e corporificadas, em vez de o Outro separado deste Um pelo abismo?

Além disso, o que significa "não livre" aqui em relação aos animais que estão numa relação instrumental com pessoas? Onde se meteu o nosso Marx zoológico agora que precisamos dele? Os animais de laboratório não são "não livres" num sentido abstrato e transcendental. Na verdade, eles têm vários graus de liberdade num sentido mais mundano, inclusive a possibilidade das experiências não funcionarem se os animais e outros organismos não cooperarem. Gosto da metáfora "graus de liberdade"; há realmente espaços não preenchidos; alguma coisa fora dos cálculos ainda pode acontecer. Até mesmo as fábricas de carne industrial têm de enfrentar o desastre da recusa de frangos e porcos de viver quando a cooperação deles é absolutamente ignorada em um excesso de arrogância da engenharia humana. Mas essa é uma maneira muito limitada de se pensar sobre liberdade animal em relações instrumentais.

\section{Trabalho e desigualdade}

O Marx na minha alma teima em me fazer retornar à categoria do trabalho, inclusive examinando as práticas atuais de extração de valor dos trabalhadores. Minha suspeita é que podemos desenvolver melhor a responsabilidade com e para outros animais examinando em profundidade a categoria do trabalho mais do que a categoria dos direitos, com sua preocupação inevitável com a semelhança, a analogia, o cálculo e a associação honorária na abstração expandida do Humano. Considerar os animais como sistemas de produção e 
como tecnologias não é nenhuma novidade. ${ }^{5}$ Levar os animais a sério como trabalhadores sem os confortos das estruturas humanistas para pessoas e animais talvez seja algo novo e possa ajudar a conter as máquinas de matar. ${ }^{6} \mathrm{O}$ sussurro pós-humanista em meu ouvido me faz lembrar que animais trabalham em laboratórios, mas não sob condições determinadas por eles próprios, e que o humanismo marxista não ajuda mais do que outros tipos de fórmulas humanistas a pensar essa questão, seja para pessoas, seja para outros animais. Acima de tudo, minha história de marxista feminista me faz lembrar que a liberdade não pode ser definida como o oposto da necessidade sem correr o risco de renegar o corpo-mente em toda a sua densidade, com todas as vis consequências de tal renegação para quem o embaraço corporal foi atribuído, tais como as mulheres, os colonizados e a lista inteira de "outros" que não podem viver na ilusão de que a liberdade vem apenas quando o trabalho e a necessidade são descartados para um outro qualquer. As relações instrumentais têm de ser reavaliadas, repensadas, vividas de outra maneira.

As marxistas feministas, todavia, não foram líderes em encarar animais face a face; elas tendiam a ficar mais do que felizes com as categorias de sociedade, cultura e humanidade, e mais do que desconfiadas da natureza, da biologia e dos relacionamentos humanos constitutivos com outras criaturas. Tanto as marxistas feministas como seus irmãos tendiam a reservar a categoria do trabalho (e de desejo e sexualidade, se não de sexo) para as pessoas. Outras feministas, no entanto, tomaram a dianteira muitos anos atrás na séria coabitação e compreensão da terra com os animais - ou, como Val Plumwood (1993) denominou a vasta heterogeneidade de presenças além dos seres humanos, "outros da terra" (Gaard, 1993; Plumwood, 1993). ${ }^{7}$ Estas teóricas

\footnotetext{
5 Ver Schrepfer e Scranton (2003) e Rader (2004) é indispensável para compreender como os significados econômico, científico, cultural e institucional de natural e de artificial são negociados na modelagem de organismos experimentais.

6 Nas décadas de 1970 e 1980, as feministas marxistas enfrentaram uma tarefa de certa forma análoga ao mostrar como muito do que as mulheres em diferentes situações fazem não seria considerado trabalho na análise marxista clássica, na qual a figura do trabalhador masculino e sua família lembra a relação estrutural de seres humanos e seus animais. A questão foi transfigurada fundamentalmente em Nancy Hartsock (1983). Levar a sério o trabalho sensorial de animais em diferentes situações pode ser mais fácil para as feministas atuais por causa dessa história.

7 As feministas também defenderam cedo, bem e com frequência o cuidado em todos os sentidos como uma pratica necessária fundamental. Para escritos de jovens feministas do século XXI sobre cuidado, ver María Puig de la Bellacasa (2008) em "Pensando com cuidado" no contexto do grupo feminista europeu Nextgenderation. Ver também Haraway (2008, cap. 1, nota 19).
} 
feministas observaram com atenção uma grande variedade de animais lisos, peludos, escamados, carnudos (e também outros organismos) e não apenas seres literários, filosóficos e linguísticos, embora também tivessem muito a dizer sobre estes últimos. ${ }^{8}$ Tenho intimidade com o trabalho dessas feministas, sou nutrida e instruída por ele, mesmo resistindo à tendência de condenar todas as relações de instrumentalidade entre os animais e as pessoas por envolverem necessariamente objetificação e opressão de tipo semelhante às objetificações e opressões do sexismo, do colonialismo e do racismo. Acho que, diante das terríveis semelhanças, foi dada demasiada ênfase à crítica sem um esforço suficiente para ver o que mais vem acontecendo na fabricação humano-animal de mundos instrumentais e o que mais é necessário. ${ }^{9}$

Estar em uma relação de uso um com o outro não é a definição de não liberdade e violação. Tais relações quase nunca são simétricas ("iguais" ou calculáveis). Em vez disso, as relações de uso são exatamente aquelas das espécies companheiras: as ecologias de outros significantes envolvem companheiros à mesa do refeitório, com indigestão e sem o conforto do propósito

\footnotetext{
Entre muitos exemplos, considere o delicado tratamento por Eileen Crist (1999) das maneiras como a linguagem molda a compreensão e as relações dos escritores, inclusive escritores científicos, com os animais. O trabalho dela é fundamental para mostrar como funciona o fato de atribuir a ação sensata apenas aos humanos e o comportamento insensato aos animais. Sempre em sintonia carnal e textual com os cães, acho que o novo livro de Alice Kuzniar (2006), é extraordinário. Melancholia's dog é um livro arriscado e impróprio; isto é, Kuzniar nos dá um trabalho de fina inteligência intelectual e emocional e leva realmente a sério o que acontece afetivamente entre os cães e as pessoas. Em sintonia com a tristeza da ligação não reconhecida e repudiada entre diferentes espécies, Kuzniar se dirige a nós, seres humanos, que recusamos a entender que nós é que temos de aprender a compreender - ou pelo menos simplesmente notar - a profundidade, a dificuldade e a urgência das relações canino-humanas, para que possamos aprender finalmente a falar com propriedade de questões como perda e morte dos animais de estimação, vulnerabilidade compartilhada e ressonância de pesar empático. Melancholia's dog entra amorosamente em obras de arte visuais e literárias a fim de tornar palpável a necessidade urgente de nutrir a prática de respeito articulado pelas complexidades de nossas ligações nas fronteiras da diferença entre espécies. Fazendo uso de filosofia, psicanálise e cinema, Erica Fudge (2002) também nos faz repensar fundamentalmente o que é e pode ser relacionar-se com animais. Toda a série da Reaktion Books sobre animais (Cão, Barata, Corvo, Ostra, Rato, e outros), sob a editoria de Jonathan Burt, está cheia de percepções, materiais e análises notáveis.

9 Entre obras indispensáveis incluem-se: Adams e Donovan (1995), Adams (1995), Birke (1994), e Bryld e Lykke (2000). Adams considerou especialmente as questões de racismo e os empecilhos no caminho da solidariedade necessária para o trabalho feminista antirracista e pró-animal eficiente. Ver também Hogan (1998), Le Guin (1998) e Walker (1987).
}

Horizontes Antropológicos, Porto Alegre, ano 17, n. 35, p. 27-64, jan./jun. 2011 
teleológico vindo de cima, de baixo, pela frente ou por trás. Isso não é nenhum tipo de reducionismo naturalista; isso se refere a viver responsivamente como seres mortais onde viver e matar não são opcionais ou passíveis de serem "lavados", como se fossem dinheiro roubado, pela criação de abismos intransponíveis nos caminhos através dos quais os fluxos de valor possam ser rastreados. Os fluxos de valor podem ser rastreados, graças a Marx e seus herdeiros; mas a resposta tem de adentrar território não trilhado, sem nem mesmo as placas de orientação de precipícios confiáveis.

Nada disso me deixa esquecer que chamei os animais de laboratório de não livres em algum sentido não desfeito pela lembrança de que as relações de utilidade não são a fonte daquela atribuição. Baba Joseph não disse que compreender o sofrimento dos animais faz dissipar a maldade de causar-lhes dor. Ele disse apenas que "pode ser que Deus [o] perdoe". Pode ser. Quando digo "não livre", quero dizer que a dor real, física e mental, inclusive muita matança, é frequentemente causada diretamente pelo aparato instrumental, e a dor não é suportada simetricamente. Nem podem, o sofrimento e a morte, ser suportados simetricamente, na maioria dos casos, por mais que as pessoas se esforcem para responder. Para mim, isso não significa que as pessoas nunca possam se envolver em práticas experimentais com animais de laboratório, inclusive causando dor e matando. Significa que tais práticas não devem deixar nunca seus praticantes em conforto moral, convencidos de sua retidão. A categoria de "culpado" também não se aplica, embora com Baba Joseph eu esteja convencida de que a palavra malvado continua apropriada. ${ }^{10} \mathrm{~A}$ sensibilidade moral necessária aqui é impiedosamente mundana e não se deixará serenar com cálculos sobre meios e fins. A moralidade necessária, a meu ver, está cultivando uma capacidade radical de lembrar e sentir o que está acontecendo e desempenhando o trabalho epistemológico, emocional e técnico para responder praticamente diante da complexidade permanente não resolvida por hierarquias taxonômicas e com nenhuma garantia humanista filosófica ou religiosa. Graus de liberdade, com certeza; o aberto não é confortável.

${ }^{10}$ Como Katie King, amante como eu de Nancy Farmer, me escreveu sobre Baba Joseph, "também estou interessada em saber o que significa estar disposto a ser malvado porque é importante" (e-mail, 11/07/2006). 


\section{Partilha não mimética}

Baba Joseph não se propôs a ficar no lugar dos porquinhos-da-índia; em vez disso, ele tentou compreender a dor deles da maneira mais literal. Há um elemento de mimese em suas ações que eu afirmo: sentir em sua carne o que os porquinhos-da-índia aos seus cuidados sentem. ${ }^{11}$ Estou extremamente interessada, todavia, em outro aspecto da prática de Baba Joseph, um elemento que chamarei de partilha não mimética. Ele submeteu-se a picadas não para se arvorar em objeto experimental, mas para compreender a dor dos roedores a fim de fazer o que pudesse, nem que fosse apenas dar testemunho da necessidade de algo corretamente chamado de perdão mesmo nos casos mais completamente justificados de causação de sofrimento. Ele não se demitiu do emprego (para morrer de fome? ou "só" para perder seu status na sua comunidade?) ou tentou convencer Nhamo a não ajudar o Dr. van Heerden no laboratório. Mesmo assim, Joseph tinha seu Deus e a esperança de por ele ser perdoado. O que ter necessidade de perdão pode significar quando não se fala com Deus e não se pratica sacrifício? Suspeito que o tipo de perdão que nós mortais que vivemos com outros animais esperamos é a graça mundana de evitar a separação, a certeza autocomplacente e a inocência mesmo nas nossas práticas mais confiáveis que reforçam a vulnerabilidade desigual.

Em um ensaio intitulado "HomemFêmea ${ }^{\circ}$ Encontra_OncoRato ${ }^{\mathrm{TM}}$ ", confrontei uma criatura geneticamente engendrada em laboratório, patenteada com o nome de OncoRato, cujo trabalho era servir de modelo de câncer de mama para mulheres. Comandada por seu sofrimento e movida pelo quadro A paixão do OncoRato pintado por Lynn Randolph, mostrando um quimérico rato com mamas de uma mulher branca e uma coroa de espinhos numa câmara de observação multinacional que era um laboratório, argumentei:

\footnotetext{
11 Baba Joseph não é um importante cientista, mas um cuidador de animais e assistente de pesquisa. Sua posição na hierarquia científica é semelhante àquela mais frequente entre animais e pessoas nos laboratórios de pesquisa biomédica hoje em dia. Ao escrever sobre a tensão afetivo-cognitiva entre o sofrimento dos animais de laboratório e das pessoas que vivem com HIV/AIDS, Eric Stanley me lembrou que técnicos de laboratório com baixos salários e poucos graus de liberdade em sua prática de trabalho são os humanos mais frequentes "na presença de" animais em sofrimento nas indústrias mecanizadas de testes de drogas e outras investigações tecnocientíficas de envergadura.
} 
O OncoRato ${ }^{\mathrm{TM}}$ é meu irmão, e melhor dizendo, macho ou fêmea, ele/a é minha irmã [...]. Embora sua promessa seja decididamente secular, ele/a é uma figura no sentido desenvolvido dentro do realismo cristão: ele/a é nosso bode expiatório; ele/a carrega o nosso sofrimento; ele/a significa e representa nossa mortalidade de uma maneira poderosa, historicamente específica, que promete um tipo culturalmente privilegiado de salvação secular - uma "cura para o câncer". Concorde eu ou não com sua existência e seu uso, ele/a sofre, fisicamente, repetidamente, e profundamente, para que eu e minhas irmãs possamos viver. No modo de vida experimental, ele/a é o experimento [...]. Se não em meu próprio corpo, certamente nos corpos de minhas amigas, eu terei um dia uma grande dívida com o/a OncoRato ${ }^{\mathrm{TM}}$ ou com seus parentes subsequentemente engendrados. Então, quem é ele/a? (Haraway, 1997, p. 79).

É tentador ver minha irmã OncoRato como um sacrifício, e com certeza a encenação cristã mal secularizada da aia sofredora a serviço da ciência, assim como o idioma cotidiano usado no laboratório para descrever o sacrifício de animais experimentais, atraem esse pensamento. O OncoRato, sem sombra de dúvida, é um modelo substituto para corpos humanos experimentais. Mas algo que a bióloga Barbara Smuts (2001a) chama de copresença com animais é o que não me deixa à vontade com o idioma do sacrifício. Os animais nos laboratórios, inclusive o OncoRato, têm face; eles são alguém e também alguma coisa, assim como nós humanos somos tanto sujeitos quanto objetos o tempo todo. Estar atento a isso é reconhecer a copresença em relações de uso e portanto lembrar que nenhuma planilha de custo e benefício será suficiente. Posso (ou não) ter boas razões para matar, ou para fazer, oncoratos, mas não tenho a majestade da Razão e o consolo do Sacrifício. Eu não tenho razão suficiente, apenas o risco de fazer alguma maldade porque isso pode ser também uma coisa boa no contexto das razões mundanas. Além disso, essas razões mundanas são inextricavelmente afetivas e cognitivas quando têm algum valor. A razão sentida não é razão suficiente, mas é o que nós, mortais, temos. A graça da razão sentida é que ela está sempre aberta a uma cuidadosa reconsideração.

Estou tentando pensar sobre o que se exige das pessoas que usam outros animais desigualmente (em experimentos, direta ou indiretamente, na vida cotidiana, aprendendo e comendo por causa do labor sentido dos animais). Algumas relações instrumentais deveriam ser encerradas, algumas deveriam 
ser alimentadas, mas nada disso sem resposta, isto é, consequências não mecânicas e moralmente alertas para todas as partes, humanas e não, na relação de uso desigual. Não acho que um dia teremos um princípio geral para o que significa partilhar sofrimento, mas ele tem de ser material, prático e consequente, o tipo de envolvimento que não deixe a desigualdade tornar-se senso comum ou ser tomada como obviamente aceitável. A desigualdade está nas práticas laborais exatas e mutáveis do laboratório, não em alguma excelência transcendente do Humano sobre o Animal, que pode então ser morto sem que a acusação de assassinato seja feita. Nem a luz pura do sacrifício, nem a visão noturna do poder de dominação iluminam os relacionamentos em jogo.

A desigualdade no laboratório é, em suma, não de um tipo humanista, seja religioso ou secular, mas de um tipo inapelavelmente histórico e contingente, que jamais aquieta o murmúrio de multiplicidade não teológica e não hierárquica que é o mundo. As questões que então me interessam são: como podem as práticas laborais multiespécie do laboratório ser menos letais, menos dolorosas e mais livres para todos os trabalhadores? Como pode a responsabilidade ser praticada entre todos os seres terrenos? O trabalho como tal, que é sempre apropriado às relações instrumentais, não é o problema; é a questão sempre urgente de sofrimento não simétrico e morte. E bem-estar não mimético.

Matar

Jacques Derrida esteve espreitando por um bom tempo nessa reflexão, e é hora de convidá-lo a entrar de uma vez. Incansável e eloquente, Derrida lembra a seus leitores que a responsabilidade nunca é calculável. Não há fórmula para resposta; de forma mais precisa, responder não é apenas reagir com um cálculo fixo apropriado para as máquinas, a lógica e - a maior parte da filosofia ocidental insistiu - os animais. Na linhagem de filósofos ocidentais com e contra quem Derrida debateu a vida inteira, só o Humano pode responder; animais reagem. O Animal está posicionado para sempre do outro lado de um abismo sem pontes possíveis, um abismo que dá ao Humano confiança em sua excelência pelo próprio empobrecimento ontológico de um mundo da vida que não pode ser seu próprio fim ou conhecer sua própria condição. Seguindo Lévinas na subjetividade do refém, Derrida lembra que nesse abismo reside a 
lógica do sacrifício, dentro da qual não existe nenhuma responsabilidade para com o mundo vivo, a não ser o humano. ${ }^{12}$

Dentro da lógica do sacrifício, só os seres humanos são assassinados. Os humanos podem e devem responder uns aos outros e talvez evitar crueldade deliberada com outros seres vivos, quando é conveniente, a fim de evitar danos à sua própria humanidade, sendo esse o escandaloso esforço maior de Kant sobre o tópico, ou, na melhor das hipóteses, reconhecer que outros animais sentem dor ainda que não possam responder ou exigir por eles próprios uma resposta. Todo ser vivo exceto o Homem pode ser matado, mas não assassinado. Tornar o Homem meramente matável é o cúmulo da indignidade moral; na verdade, é a definição de genocídio. Reação é para e em direção ao que não é livre; resposta é para e em direção ao aberto. ${ }^{13}$ Tudo menos o Homem vive no reino da reação e, portanto, o cálculo; tanto de dor animal, tanto de bem humano, some tudo, mate tantos animais, chame isso de sacrifício. Faça a mesma coisa para as pessoas e elas perderão sua humanidade. Uma grande quantidade de história demonstra como tudo isso funciona; basta checar as relações mais recentes de genocídios em andamento. Ou ler as listas dos corredores da morte nas prisões dos Estados Unidos.

12 Ver Jacques Derrida e Jean-Luc Nancy (1991). Sacrificio é uma palavra comum com muitos significados, nem todos contidos nas análises de Derrida, mas o tratamento que ele dá à lógica do sacrifício nas tradições judaica e cristã, inclusive de seus herdeiros e irmãos seculares na história da filosofia, é importante. Para decepção crítica com os esforços de Derrida, ver Wood (1999). Para leituras e extensões detalhadas e astutas dos escritos extraordinários de Derrida sobre questões animais em filosofia, ver Wolfe (2003), especialmente seu capítulo sobre o fracasso dos discursos de direitos, "Old orders for new: ecology, animal rights, and the poverty of humanism", e seu ensaio sobre Derrida e Lévinas (entre outros), "In the shadow of Wittgenstein's lion: language, ethics, and the question of the animal". Para outra bem argumentada insistência sobre a irredutível multiplicidade de animais e os relacionamentos historicamente contingentes que os humanos têm com animais, ver Smith (2004). Infelizmente, filósofos como Derrida geralmente não leem, citam ou reconhecem como filosofia as amplas literaturas feministas indicadas nas minhas notas acima. Eu culpo por isso menos o "filosofema" do Animal e mais o do Homem e suas práticas de citação ciclópicas, desprovidas de curiosidade! Frequentemente, o trabalho feminista esteve primeiro e também menos envolvido nas armadilhas do falso reconhecimento de animais como singulares, mesmo que tenhamos estado igualmente presas nas redes do humanismo e precisemos do tipo de pensamento praticado por Derrida e Gayatri Spivak.

${ }^{13}$ Esse tipo de "aberto" é elucidado na leitura de Heidegger por Agamben (2004). Ele, Agamben, explica muito bem como a "máquina antropológica" funciona na filosofia. No meu modo de ver, não obstante a vida nua (bare life), ele absolutamente não ajuda a entender como se chega a outro tipo de abertura, o tipo que as feministas e os outros que jamais tiveram o ponto de partida de Heidegger para o Dasein do tédio profundo possam discernir.

Horizontes Antropológicos, Porto Alegre, ano 17, n. 35, p. 27-64, jan./jun. 2011 
Derrida compreendeu que essa estrutura, essa lógica do sacrifício e essa posse exclusiva da capacidade de resposta, é o que produz o Animal, e ele chamou essa produção de criminosa, um crime contra seres que chamamos de animais.

A confusão de todas as criaturas vivas não humanas dentro da categoria comum e geral do animal não é simplesmente um pecado contra o pensamento, a vigilância, a lucidez ou a autoridade empírica rigorosos; é também um crime. Não exatamente contra a animalidade, mas um crime de primeira grandeza contra os animais, contra animais" (Derrida, 2002, p. 417). ${ }^{14}$

Tal criminalidade ganha força histórica especial diante da violência imensa e sistemática contra animais que merece o nome de "exterminismo". Como diz Derrida (2002, p. 394-395),

ninguém pode negar mais este evento, ninguém pode negar a sujeição em proporções sem precedentes do animal. [...] Todo mundo sabe que quadros aterrorizantes e insuportáveis um pintor realista poderia fazer da violência industrial, mecânica, química, hormonal e genética à qual o homem vem submetendo a vida animal nos últimos dois séculos. ${ }^{15}$

Todo mundo pode saber, mas não há nem de longe bastante indigestão. ${ }^{16}$

${ }^{14}$ Ver também Derrida (2003).

${ }_{15}$ Para uma vívida arte gráfica só sobre essas questões, ver Coe (2000), e www.graphicwitness.org/coe/ coebio.htm. Coe trabalha dentro de um quadro de direitos dos animais e proibição crítica incondicional de comer ou fazer experimentos em animais. O testemunho dela é radical. Acho que seu trabalho visual é sedutor, mas suas formulações políticas e filosóficas, nem tanto. Estendida à crítica do especismo, a lógica do humanismo e dos direitos está em toda parte e a substância de ação moral é denúncia, proibição e resgate, de modo que, no meio das relações instrumentais, os animais só podem ser vítimas. Ainda assim, suas imagens têm a força das visões de William Blake e Pieter Bruegel, e preciso das chamas dos seus olhos para polir o meu conhecimento de inferno - um inferno pelo qual o meu mundo, eu inclusive, é responsável.

${ }^{16}$ As estatísticas de animais mortos por pessoas no mundo inteiro para uso em quase todo aspecto de vida humana são realmente assombrosas (fáceis de obter - olhe na internet) e o crescimento dessa matança no último século é, literalmente, impensável, se não incontável. O crescimento assombroso da população humana nesse mesmo período faz parte da razão, mas não chega a explicar a escala da matança de animais. A publicidade de um importante livro novo afirma simplesmente que matar é a forma mais comum de interação humana com animais. Ver Animal Studies Group (2006). Qualquer um que olhar a destruição de frangos e outras aves para afastar o risco de a gripe aviária se espalhar entre as pessoas não terá nenhuma dúvida sobre tais afirmações. Não levar toda essa matança a sério é não ser uma pessoa séria no mundo. Como levar isso a sério não é nem um pouco óbvio. 
Dentro da lógica de sacrifício que alicerça todas as versões de humanismo religioso ou secular, os animais são sacrificados exatamente porque podem ser mortos e ingeridos simbólica e materialmente em atos que não são vistos como canibalismo ou assassinato do irmão pela lógica de sub-rogação e substituição. (Derrida entendeu que patricídio e fratricídio são os únicos assassinatos verdadeiros na lógica do humanismo; todas as demais pessoas a quem se aplica a lei estão cobertas por cortesia.) O substituto, o bode expiatório, não é Homem, mas Animal. ${ }^{17} \mathrm{O}$ sacrifício funciona; há todo um mundo daqueles que podem ser mortos, porque afinal eles são apenas alguma coisa, não alguém, perto bastante de "ser" a fim de serem um modelo, substituto, suficientemente semelhantes e, portanto, alimento nutritivo, mas não perto bastante para forçar uma resposta. Não o Mesmo, mas Diferente; não Um, mas Outro. Derrida repudia essa armadilha com todo o considerável poder técnico de desconstrução e toda a sensibilidade moral de um homem que é afetado pela mortalidade compartilhada. Julgando que o crime que se justifica postulando o Animal é mais que idiotice (uma besteira), Derrida (2002, p. 408) vai muito mais longe: "O gesto me parece constituir filosofia como tal, o próprio filosofema."

Derrida afirma que o problema não é os seres humanos recusarem alguma coisa a outras criaturas - linguagem, conhecimento da morte, ou seja qual for o sinal teórico-empírico do Grande Abismo popular no momento - mas sim a arrogância desafiadora da morte de atribuir positividades tão maravilhosas ao Humano. "A questão do dito animal na sua totalidade acaba sendo saber não se o animal fala, mas se se pode saber o que significa responder. E como distinguir uma resposta de uma reação." (Derrida, 2002, p. 377, grifo do autor). Tomando como pressuposto a irredutível multiplicidade de seres vivos, Homo sapiens e outras espécies, que estão emaranhados na mesma rede,

17 Que Jesus foi um sacrifício está intrínseco no santo escândalo das Boas Novas. Ao contrário do primeiro Isaac, para quem um animal substituto foi providenciado em cima da hora, o Filho do Homem provocou seu próprio sacrifício e isso agradou seu Pai. O bonito sobre os cristãos que levam essa história a sério é que eles entendem que, assim de repente, o Homem está sujeito a ser morto sem que isso seja assassinato. Jesus é um bode expiatório para acabar com todos os sub-rogados, e sua comida foi uma festa que já dura mais de dois mil anos. Isto é realmente um problema sério para a lei. Não surpreende que o secularismo nunca satisfaça os consumidores desse sacrifício fora de série e que não para de ser repetido. Minha alma pagã feminista junto com minha ética de trabalho multiespécie acha que podemos nos sair melhor do que tanto o carnal Filho do Homem quanto seus irmãos seculares mais etéreos. 
sugiro que essa questão de discernimento gira em torno dos relacionamentos de uso e dilemas de matança não resolvidos.

Tenho medo de começar a escrever o que estive pensando sobre tudo isso, porque posso entender errado - emocional, intelectual e moralmente - e a questão carrega consequências. Hesitantemente, vou tentar. Sugiro que é um passo errado separar os seres do mundo em seres que podem e que não podem ser mortos e um passo errado fingir viver fora da matança. $\mathrm{O}$ mesmo tipo de engano viu liberdade apenas na ausência do trabalho e da necessidade, ou seja, o engano de esquecer as ecologias de todos os seres mortais, que vivem no e através do uso dos corpos uns dos outros. Isso não quer dizer que a natureza se ensanguenta com garras e dentes e, portanto, vale tudo. A falácia naturalista é o passo errado espelhado do humanismo transcendental. Acho que o que meu povo e eu precisamos largar se quisermos aprender a cessar o exterminismo e o genocídio, seja através de participação direta ou de benefício indireto e aquiescência, é o mandamento "Não matarás". O problema não é descobrir a quem tal mandamento se aplica de modo que a matança de "outros" possa continuar como de costume e atingir proporções históricas sem precedentes. O problema é aprender a viver responsavelmente dentro da multíplice necessidade e labuta de matar, para então assumir isso com transparência, em busca da capacidade de responder em inexorável contingência histórica, não teleológica e multiespécies. Talvez o mandamento deva ser "Não tornarás matável".

O problema de fato é compreender que os seres humanos não têm liberada a necessidade de matar outros significantes, que estão eles próprios respondendo, não apenas reagindo. No idioma laboral, os animais são sujeitos de trabalho, não apenas objetos trabalhados. Por mais que tentemos nos distanciar, não há nenhuma maneira de viver que não seja também uma maneira de mais alguém, não apenas mais alguma coisa, morrer diferenciadamente. Os veganos conseguem isso tanto quanto quaisquer outros, e o trabalho deles para evitar comer ou vestir qualquer produto animal levaria a maioria dos animais domésticos ao status de coleções de patrimônio protegido ou ao simples extermínio como tipos e como indivíduos. Eu não discordo que o vegetarianismo, o veganismo e a oposição à experimentação com animais sencientes possam ser posições feministas poderosas; discordo que sejam doxa feminista. Além disso, acho que o feminismo fora da lógica do sacrifício tem de encontrar uma maneira de honrar o trabalho intrincado de humanos e animais juntos em ciência e em muitos outros campos, inclusive o do melhoramento animal desde o 
início até chegar à mesa. Não é matar que nos leva ao exterminismo, mas sim tornar os animais matáveis. Baba Joseph compreendeu que os porquinhos-daíndia não eram matáveis; ele tinha a obrigação de responder.

Acho que isso é exatamente o que David Lurie, o assediador sexual e professor de poesia de meia idade, no romance Desonra, de J. M. Coetzee (1999), compreendeu. Trabalhando com uma veterinária que cumpria o seu dever para com inúmeros animais doentes e abandonados matando-os em sua clínica, Lurie trouxe a ela o cão ao qual ele tinha se apegado, para eutanásia, no fim do romance. Ele poderia ter adiado a morte daquele cão único. Aquele cão importava. Ele não sacrificou aquele cão; ele assumiu a responsabilidade de matar sem, talvez pela primeira vez na vida, escapar. Ele não se refugiou na linguagem do matar humanizado; ele era, afinal, mais honesto e capaz de amar do que aquilo. Essa incalculável resposta moral é o que, para mim, distingue David Lurie em Desonra de Elizabeth Costello em $A$ vida dos animais, para quem animais de fato existentes não parecem estar presentes. Elizabeth Costello, a conferencista (Tanner Lecturer) ficcional em $A$ vida dos animais de Coetzee (2001), se encastela em uma linguagem radical de direitos dos animais. Mostrando um comprometimento audaz com a razão soberana, ela não titubeia diante de qualquer das pretensões universais desse discurso e avoca todo o seu poder para nomear a atrocidade extrema. Ela pratica o método de iluminação da história comparativa para consertar a horrenda igualdade da matança. Comer carne é como o holocausto; comer carne é o holocausto. O que Elizabeth Costello faria se estivesse no lugar de Bev Shaw, o cuidador de animais voluntário em Desonra, cuja tarefa de amor diária é levar grandes números de cães e gatos abandonados ao consolo da morte? Talvez não haja consolo para aqueles animais, a não ser morrer. O que Costello faria no lugar de Lucy Lurie de Desonra, cuja vida cara a cara com cães e vizinhos humanos na África do Sul pós-apartheid detém o poder categórico das palavras no meio de sua pronunciação? Ou mesmo de David Lurie, o desgraçado pai de Lucy, que finalmente acede a um discurso de desejo pelo menos tão audaz e autêntico quanto o discurso obliterador de distinções de Elizabeth Costello sobre o sofrimento universal? Como, no romance Desonra, o sofrimento e os dilemas morais que ocorrem inexoravelmente nas relações face a face, historicamente situados e para além da linguagem, interagem com as demandas morais cheias de generalizações e categorias abstratas de $A$ vida dos animais? E quem vive e quem morre - animais e humanos - nas muitas diferentes maneiras de herdar 
as histórias de atrocidade que Coetzee propõe nas práticas de investigação moral desses romances? ${ }^{18}$

Eu sugiro que o que segue da intuição feminista que abraçou corpos-mentes, historicamente situados, como lugar não apenas do nascimento primeiro (materno), mas também da vida plena e todos os seus projetos, fracassados e bem-sucedidos, é que os seres humanos precisam aprender a matar responsavelmente. E a serem mortos responsavelmente, almejando a capacidade de responder e reconhecer resposta, sempre com razões, mas sabendo que nunca haverá razão suficiente. Não podemos nunca abdicar da técnica, do cálculo, das razões, mas essas práticas jamais nos levarão àquele tipo de espaço onde a responsabilidade multiespécies está em jogo. Por esse espaço, não cessaremos de reclamar um perdão que não podemos exigir. Não acho que podemos alimentar o viver até aprender melhor a encarar o matar. Mas também aprender melhor a morrer em vez de matar. Às vezes uma "cura" para o que nos mata, seja o que for, simplesmente não é razão suficiente para manter as máquinas de matar funcionando no nível ao qual nós (quem?) nos acostumamos.

\section{Cuidar}

É sempre estimulante voltar ao laboratório depois de visitar grandes filósofos e os lugares horríveis em que a gente se mete por causa deles. Deixem-me revisitar os cães hemofílicos em "Cães de valor agregado e capital animado" - capítulo 2 de When species meet (Haraway, 2008). Lá nós vimos que os cães que sofriam de hemofilia tornaram-se pacientes-modelos, bem como substitutos e tecnologias para o estudo de uma doença humana, ao longo dos anos iniciados no final da década de 1940 no laboratório de Kenneth Brinkhous

${ }^{18}$ Ver também J. M. Coetzee (1999, 2001). Barbara Smuts (2001b) fez uma queixa semelhante sobre a ausência de criaturas reais em $A$ vida dos animais. Cary Wolfe (2008) escreve sobre David Lurie e Elizabeth Costello. A personagem de ficção Elizabeth Costello tem uma relação muito mais complexa com a adequação do discurso de direitos e razão em Coetzee (2003), quando ela enfrenta um colapso de linguagem do tipo que penetra fundo e mexe com nossas entranhas. Mesmo assim, as conferências Tanner Lectures representam uma abordagem comum, poderosa e, na minha opinião, poderosamente errada das dificuldades de matar e da matabilidade de animais e humanos. Não é que a matança de judeus e outros pelos nazistas e o extermínio massivo de animais na indústria de carne não tenham relação; é que a analogia que culmina em equação pode embotar nossa atenção para a diferença e a multiplicidade irredutíveis e suas demandas. Atrocidades diferentes merecem suas próprias linguagens, mesmo que não haja palavras para o que fazemos.

Horizontes Antropológicos, Porto Alegre, ano 17, n. 35, p. 27-64, jan./jun. 2011 
na Universidade da Carolina do Norte em Chapel Hill (Pemberton, 2003). Compartilhar o sofrimento dos cães, ou o dos participantes nos experimentos de hoje, não significa imitar aquilo a que os caninos são submetidos num tipo de fantasia masoquista heroica, mas fazer o trabalho de dar atenção e garantir que o sofrimento seja mínimo, necessário e consequente. Se qualquer uma dessas garantias for considerada impossível, o que é sempre um julgamento arriscado feito na base de razões, mas sem a garantia da Razão, então o trabalho responsável é fazer parar o empreendimento. É bem provável que quebrar a lógica sacrificial que define quem deve e quem não deve ser morto leve a muito mais mudança do que as práticas de analogia, extensão de direitos, denúncia e proibição. Os exemplos poderiam incluir estar seguro de que os experimentos são bem planejados e executados; arranjar tempo para praticar o cuidado entre e para com todas as pessoas e organismos no laboratório e nos mundos alcançados por aquele laboratório, mesmo se os resultados vierem mais lentamente ou custarem mais ou as carreiras não forem tão meteóricas; e praticar as habilidades cívicas do envolvimento político e da presença cultural nesses tipos de questões, inclusive as habilidades de responder, não de reagir, ao discurso daqueles que não consideram essas práticas científicas benéficas ou necessárias. Nada disso faz a palavra maldoso desaparecer; eu não estou advogando a limpeza da alma pelo reformismo higiênico. Estou advogando o entendimento de que os seres heterogêneos da terra estão juntos nessa rede para todo o sempre e ninguém nela chega a ser O Homem.

A bióloga molecular de plantas Martha Crouch sugere que alguns dos prazeres das ciências de laboratório que levam seus praticantes a ser menos inclinados ao engajamento na cosmopolítica vêm de uma pré-adolescência tipo Peter Pan, na qual a pessoa nunca tem realmente de encarar a materialidade semiótica completa de suas práticas científicas (Haraway, 1997, p. 110-112). Se ela tiver razão, talvez a partilha do sofrimento se refira a crescer para fazer o tipo de trabalho que também é jogo duro, caro, que leva tempo, de ficar com todas as complexidades para todos os atores, mesmo sabendo que não será nunca totalmente possível, totalmente calculável. Ficar com as complexidades não significa não agir, não fazer pesquisa, não se envolver em alguns, aliás, muitos, relacionamentos instrumentais desiguais; significa aprender a viver e pensar em abertura prática para a dor e mortalidade compartilhadas e aprender o que esse viver e pensar ensinam. 
O sentido de cosmopolítica em que me inspiro é de Isabelle Stengers. Ela invocou o idiota descrito por Deleuze, aquele que sabia como desacelerar as coisas, a fim de parar a corrida ao consenso ou a um novo dogmatismo ou à denúncia, para dar possibilidade a um mundo comum. Stengers insiste que nós não podemos denunciar o mundo em nome de um mundo ideal. Os idiotas sabem disso. Para Stengers, o cosmos é o desconhecido possível construído por entidades múltiplas e diversas. Cheio da promessa de articulações que seres diversos podem eventualmente fazer, o cosmos é o oposto de um lugar de paz transcendente. A proposta cosmopolítica de Stengers, no espírito do anarquismo comunitário feminista e o idioma da filosofia de Whitehead, é que as decisões devem acontecer de alguma forma na presença daqueles que sofrerão suas consequências. Tornar concreto esse "de alguma forma" é o trabalho de praticar combinações engenhosas. Stengers é formada em química, e as combinações engenhosas são o seu ofício. Chegar "na presença de" requer trabalho, invenção especulativa e riscos ontológicos. Ninguém sabe como fazer isso antes de se juntar em composição (Stengers, 2005). ${ }^{19}$

Para aqueles cães hemofílicos em meados do século XX, sua labuta fisiológica exigiu do pessoal humano de laboratório a labuta correspondente de cuidar dos cães como pacientes nos mínimos detalhes antes de dirigir questões a eles enquanto sujeitos experimentais. É evidente que de outra forma a pesquisa teria fracassado, mas essa não é toda a história - ou não se deve permitir que seja toda a história quando as consequências de partilhar o sofrimento não mimeticamente se tornarem mais claras. Por exemplo, quais tipos de arranjos no laboratório minimizariam o número de cães necessários? Tornariam as vidas dos cães tão plenas quanto possível? Envolveriam os cães como corpos-mentes, em relacionamentos de correspondência? Como conseguir financiamento para contratar um especialista em biocomportamento para treinar tanto os animais de laboratório como as pessoas em todos os níveis, desde os principais pesquisadores até os funcionários da sala de animais? ${ }^{20} \mathrm{Como}$

19 Ver também Stengers (2003a, 2003b). Stengers está tendo uma longa e rica conversa com Bruno Latour sobre cosmopolítica - ver Latour (2004).

20 Treinar animais de uma enorme variedade de espécies, de polvos a gorilas, para cooperar ativamente com as pessoas em protocolos científicos e melhoramento, assim como treinar assistentes humanos para oferecer enriquecimento comportamental inovador aos animais aos seus cuidados, é uma prática em expansão. Os animais treinados são submetidos a menos coerção tanto do tipo físico como farmacêutico. Tais animais são mais calmos, mais interessados nas coisas, mais capazes de tentar algo novo em suas vidas, e

Horizontes Antropológicos, Porto Alegre, ano 17, n. 35, p. 27-64, jan./jun. 2011 


\section{envolver humanos com hemofilia ou humanos que se importam com pessoas com hemofilia no cuidado dos cães? Como perguntar na prática se esses tipos de experimentos ainda merecem florescer, sem antever a resposta através de um cálculo sobre quanta e de quem é a dor que tem importância? Se não, de}

respondem melhor. Pesquisa científica anterior, como também ouvir finalmente um pouco as pessoas que trabalham com animais em entretenimento e esporte, produziu conhecimento novo que por sua vez muda as possibilidades e obrigações morais em relacionamentos instrumentais como aqueles nos laboratórios de animais experimentais. A ciência animal experimental, nesse caso a psicologia comportamental e comparativa, produziu conhecimento crucial para mudar as condições de trabalho de pessoas e de animais na ciência animal experimental. Responder significa também aprender a conhecer mais; aprender a aprender não é algo que apenas os animais em condições operacionais fazem. Para aprender a aprender é preciso descobrir como coabitar um mundo de multiespécies moldado por rios de confiança adquirida. $\mathrm{O}$ treinamento envolve um relacionamento assimétrico entre parceiros responsivos. Ganhar a atenção um do outro é o cerne do relacionamento. A Aliança de Gerenciamento do Comportamento Animal (Animal Behavioral Management Alliance), fundada em 2000, é a associação profissional cujo único objetivo é treinar animais, principalmente os chamados de exóticos, vivendo em mundos de estruturação humana, para melhorar as vidas das criaturas. Uma boa narrativa jornalística de como as pessoas aprendem a melhorar as vidas de animais principalmente "não domésticos" empregados numa variedade de trabalhos, em tudo desde exibição em zoológicos, TV e cinema, até em laboratórios de pesquisa, se encontra em Sutherland (2006). Os cientistas de laboratórios experimentais percebem a ideia eventualmente. Coghlan (2006) descreve uma conferência na Royal Society em Londres enfocando as maneiras como os animais interpretam o mundo, inclusive as implicações do tratamento de animais que trabalham em pesquisa científica. Coghlan (2006, p. 6) escreve que "o Instituto para Pesquisa de Animais em Laboratório está realizando a primeira investigação em profundidade no país [Reino Unido] sobre estresse e aflição em animais de laboratório". A meta é desenvolver um conjunto de parâmetros objetivos para medir a aflição e o bem-estar em várias espécies, de modo que o cuidado possa ser mais apropriado e desvinculado de narrativas comuns e pressupostos não baseados em dados. A Royal Society foi palco dos relatos de Robert Boyle sobre as leis dos gases na Inglaterra no século XVII; talvez possamos esperar um impacto igualmente revolucionário dos relatórios de 2006. Como saber se um cão ou um rato está tendo dor? Uma resposta objetiva a esse tipo de questão pode efetivamente ser encontrada se a pessoa (a) é curiosa e (b) também se preocupa. Instrumentos falíveis comuns, como as avaliações psicométricas no contexto da medicina comparativa, são convenientes bombas pneumáticas do século XXI, evitando as teologias de debates sobre a sensitividade animal e confrontando a evacuação de coração e mente nas atuais práticas industriais com animais em ciência e outras atividades. Para um bom exemplo dos cuidados, ainda deficientes embora melhores, com o bem-estar de sujeitos experimentais caninos, ver Hubrecht (2002). Para uma exposição de pelo menos algumas condições reais para cães de pesquisa, aqueles com má sorte suficiente para estarem nas garras da Unidade Beagle da Huntington Life Sciences no Reino Unido, pelo menos entre 1996 e 2006, ver Inside Huntingdon Life Sciences ([s.d.]). A filmagem da denúncia foi ao ar no Channel 4 britânico em 2005, deflagrando uma grande campanha contra a vivissecção. Hubrecht se esforça muito para eliminar práticas como aquelas da HLS. Ele ganhou o Prêmio Bem-estar Animal de Laboratório GlaxoSmithKline em 2004. Quem dera isso pudesse acalmar meu ceticismo quanto à magnanimidade das grandes indústrias farmacêuticas... Mas o alcance e o poder do nível de cuidados elevado por Hubrecht e outros são reais e importantes. Para a abordagem de uma organização de pesquisa médica (RDS) em relação a animais em prática experimental, ver http://www.rds-online.org.uk. Um relatório da RDS afirma que havia cerca de três milhões de procedimentos científicos usando animais no Reino Unido em 2005.

Horizontes Antropológicos, Porto Alegre, ano 17, n. 35, p. 27-64, jan./jun. 2011 
quem será o sofrimento que exigirá a labuta prática da partilha não mimética? Tudo isso é cenário da minha própria imaginação, é claro, mas estou tentando retratar como seria a partilha se ela fosse incluída em qualquer decisão de usar outro ser senciente quando poder e benefício desiguais são (ou devem ser) inegáveis e não inocentes ou transparentes.

A filósofa e psicóloga belga Vinciane Despret (2004, p. 368) afirma que "articular corpos a outros corpos" é sempre uma questão política. O mesmo deve ser dito sobre desarticular corpos para rearticular outros corpos. Despret reformulou caminhos para pensar sobre domesticação entre pessoas e animais. Meu estudo reside em um dos principais locais onde os animais domésticos e sua gente se encontram: o laboratório experimental. Fiz algumas viagens paralelas a criatórios e abatedouros de animais agrícolas, impelida pelo gado na história de Baba Joseph, bestas intensamente amadas e cultivadas por Nhamo e sua gente, bestas cruelmente usadas pelas moscas-tsé-tsés e seus tripanosomas, e bestas transformadas em eficientes máquinas de fazer carne, bastante sadias e livres de parasitas, nos campos de morte do agrobusiness industrial. Estou certa de que a linguagem do trabalho e da partilha não mimética não vai ser adequada mesmo fazendo parte de uma necessária caixa de ferramentas. Quando os nossos soporíferos humanistas ou religiosos não nos satisfazem mais, nós exigimos uma grande variedade de maneiras de tornar vívidas e práticas as necessidades materiais-éticas-políticas-epistemológicas que devem ser vividas e desenvolvidas dentro de relações desiguais, instrumentais, ligando animais humanos e não humanos tanto na pesquisa quanto em outros tipos de atividades. A meu ver, aprender a compartilhar não mimeticamente a dor de outros animais é uma abertura ontológica, um problema prático e uma obrigação ética dos seres humanos. A partilha da dor promete desvendamento, promete vir a ser. A capacidade de responder pode ainda ser reconhecida e cultivada nesta terra.

Eu termino na companhia de outra escritora extraordinária, Hélène Cixous (1998), que recorda como errou ao trair abjetamente o cão da sua infância. Muitos anos depois, ela só sabia que o amava, só sabia como amá-lo, só reconhecia como ele amava. Mordida com força no pé por seu cão enlouquecido, Fips, que fora levado à insanidade da dentada pelas pedras atiradas contra a casa de sua família em Algiers após a Segunda Guerra Mundial, a menina Cixous, de 12 anos, submetida como toda a família à dor insuportável da morte do seu pai e ao opróbrio reservado aos forasteiros bodes expiatórios 
pelos árabes colonizados que os rodeavam, não pode aguentar a horrível sina do seu cão. Nenhuma complexidade de história vivida livrou sua família do rótulo de judeus franceses duplamente odiados. A família Cixous, assim como os árabes colonizados, foi transformada categoricamente em matável. Nenhuma graça de um final feliz salvou Fips das consequências. O cão, amarrado e aparentemente esperando que a menina Hélène pisasse nele, ferrou-lhe os dentes no pé, sem soltar, apesar de a menina desesperada bater nele para livrar-se. Depois disso, Cixous não pode mais encarar Fips. O cão, doente e abandonado, morreu na companhia do seu irmão. Hélène não estava lá. Já adulta, Cixous aprendeu a contar a história de Job the dog.

A história termina em tragédia. [...] Eu queria que ele me amasse assim e não assado. [...] Mas, se eles me dissessem que eu queria um escravo, eu teria respondido indignada que eu queria apenas o puro cão ideal de que tinha ouvido falar. Ele me amava como um animal e longe do meu ideal. [...] Carrego a raiva dele estampada no meu pé esquerdo e em minhas mãos. [...] Eu não trouxe claridade à sua obscuridade. Eu não murmurei para ele as palavras que todos os animais compreendem. [...] Mas ele tinha carrapatos, do tamanho de grãos-de-bico. [...] Elas o devoraram vivo, aquelas criaturas bebedoras de sangue, inventadas para matar uma vítima sem a mínima possibilidade de fugir delas, aquelas provas da existência de pequenos vampiros diabólicos que riem da falta de mãos do cão, elas o chupam até a morte, Fips sente sua vida escoar para aquela tribo de estômagos e sem chance de combatê-la. [...] Eu não o acompanhei. Um medo desleal de ver morrer aquele que não amei com força suficiente, e como eu não dava a minha vida por ele, eu não podia mais partilhar sua morte. (Cixous, 1998, p. $244-261) .{ }^{21}$

Minha história termina onde começou, com os dilemas colocados por insetos sugadores de sangue, quando a lógica do sacrifício não faz sentido e a esperança de perdão depende de aprender um amor que escapa ao cálculo, mas requer a invenção de pensamento especulativo e da prática de recordar, de rearticular corpos a corpos. Não um amor ideal, não um amor obediente, mas um amor que pode até mesmo reconhecer a multiplicidade desobediente dos insetos. E o gosto de sangue.

${ }^{21}$ Agradeço a Adam Reed por dar-me o ensaio de Cixous e por seus evidentes cuidados e dor ao lê-lo. 


\section{Coda: rearticulando}

Eu escrevi "A partilha do sofrimento" com a plena consciência de que iria, poucas semanas mais tarde, dar a palestra de abertura na conferência "Kindred spirits" ("Seres com inclinações em comum"), onde a maioria dos palestrantes e da audiência seriam veganos, ativistas da causa animal e outras pessoas conscienciosas, inclusive alguns biólogos, desconfiados da maioria dos laboratórios de pesquisas de animais..$^{22}$ Eu não planejava apresentar este trabalho lá, mas, para ser capaz de dizer qualquer coisa em boa fé naquela conferência, eu precisava escrever publicamente sobre as questões espinhosas em resposta a e junto com aquela comunidade. Falar sobre a condução responsável de pesquisa de campo ou treinamento com cães e cavalos, apesar de sério e importante, não seria cumprir minhas obrigações com as pessoas ou os animais. Faço parte da comunidade animal, humana e não humana, de Seres Aparentados, da mesma maneira como faço parte do mundo ecofeminista, para o qual escrevi o "Manifesto ciborgue" em 1985. Eu também fiz e faço parte da comunidade de ciência biológica experimental à qual aquele trabalho ciborgue também foi dirigido.

Minha amiga e colega Sharon Ghamari-Tabrizi leu "A partilha do sofrimento" em manuscrito e forçou-me a olhar de frente o que ela chama de "o caso mais difícil para a teoria de copresença e reposta":

É muito mais fácil fazer uso da noção de racionalidade transespécie nos estudos de campo em que o cientista/conhecedor pode circular pelo habitat do animal. Mas a questão mais difícil é quando o lugar é inteiramente de construção humana, onde o laboratório é um ambiente total. No laboratório, o relacionamento não é apenas desigual e assimétrico, ele é completamente enquadrado e justificado, legitimado e significado no contexto dos materiais racionalistas do primeiro humanismo moderno. Por quê? Porque está condicionado à capacidade humana de capturar, criar, manipular e compelir os animais a viver, comportarem-se, morrer dentro de seu aparato. Como isso foi justificado? Pelo poder humano

22 Alyce Miller, professora de literatura da Universidade de Indiana, escritora e advogada para o bem-estar dos animais, organizou a conferência "Kindred spirits" (em Bloomington, Indiana, de 7 a 9 de setembro de 2006) para reunir diversos estudiosos, artistas e ativistas fora do esquema de direitos dos animais versus bem-estar dos animais. As excelentes apresentações, bem como a atenta e escrupulosa presença dos participantes, continuam mexendo com a minha mente e o meu coração.

Horizontes Antropológicos, Porto Alegre, ano 17, n. 35, p. 27-64, jan./jun. 2011 
sobre o animal. Justificado no passado por direito divino e hierarquia de dominação, ou pela pretensão da razão humana quanto à necessária predação humana de outros seres.

Então, se você for abandonar o humanismo pelo pós-humanismo, a-humanismo, não humanismo dos filósofos de processo, dos fenomenologistas, de Derrida e Whitehead, ainda assim eu quero saber como as práticas experimentais especificamente de laboratório são feitas e justificadas. Esses detalhes, essas práticas mundanas são o lugar onde a política de ciência sucessora acaba sendo elaborada.

O que estou tentando dizer, Donna, é que a batalha mais difícil será travada nos verdadeiros detalhes de proibição e licença e nos detalhes de prática nos procedimentos em laboratório durante as experiências.

Eu quero saber o que você diria quando alguém lhe interceptar e disser: eu a desafio a defender a matança de animais de laboratório em experiências biomédicas. Por mais cuidadosa que você seja para protegê-los da dor extraordinária, no fim eles são submetidos à dor infligida por você em nome dos bens sociais de busca de conhecimento pela busca em si, ou aplicações para propósitos humanos. Você fez isso. Você matou os animais. Defenda-se.

$\mathrm{O}$ que você diz então ${ }^{23}$

\section{Eu escrevi de volta:}

Sim, todos os cálculos ainda valem; sim, defenderei a matança de animais pelas razões e em condições materiais-semióticas que eu julgar toleráveis por causa do cálculo de um bem maior. E não, isso nunca é bastante. Eu recuso a escolha de "direitos animais invioláveis" versus "o bem humano é mais importante". Ambas as opções são dadas como se o cálculo resolvesse o dilema, e tudo que tenho ou temos de fazer é escolher. Eu nunca considerei isso suficiente na política de aborto tampouco. Por não termos aprendido a moldar corretamente o discurso público, nas batalhas legais e populares as feministas praticamente não tiveram escolha a não ser usar a linguagem da escolha racionalista como se isso definisse o nosso perfil político, mas nós sabemos que não define. Como diz Susan Harding, nós feministas que protegemos o acesso ao aborto, nós que matamos dessa forma, precisamos aprender a reformular a vida e a morte em nossos termos e não aceitar a dicotomia racionalista que rege a maioria das disputas éticas. ${ }^{24}$

23 Sharon Ghamari-Tabrizi, comunicação pessoal (e-mail, 15/07/2006).

24 Ver Harding (2006). 
O cálculo também exige outra série de questões que as feministas envolvidas com decisões de aborto também conhecem intimamente: para quem, para que, e por quem deve ser feito um cálculo de custo-benefício, já que, em todos esses casos difíceis, sempre mais de um ser enredado no cerne da questão está em jogo? Quando eu questionei o biólogo Marc Bekoff em um painel, durante a conferência "Kindred spirits", ele afirmou categoricamente que sua pergunta contundente é: "A pesquisa beneficia os animais?" Diante da história da redução de animais de laboratório a máquinas-ferramentas e produtos para a grande farma (o complexo industrial de pesquisa farmacêutica tecnocientífica), agrobusiness, cosméticos, exibições circenses e muito mais, tal pergunta tem uma força especial. Não fazer essa pergunta com seriedade está, ou deveria estar, fora de cogitação na prática científica.

A prática de manter os animais não humanos no centro da atenção é necessária, mas não suficiente, não apenas porque outros bens morais e ontológicos competem nesse tipo de quadro de custo-benefício, mas principalmente porque o caráter mundano da espécie companheira funciona de outro modo. Uma questão como a de Berkoff não é um absoluto moral, mas uma prática necessária, mortal, focada numa história situada estarrecedora. Essa prática não reduz a força da questão, mas localiza-a na terra, em lugares reais, onde julgamento e ação estão em jogo. Além disso, animais individuais, humanos e não humanos, são eles próprios montagens enredadas de relacionamentos amarradas muitas vezes e em muitos níveis a outras montagens, orgânicas e não orgânicas. Criaturas individuadas são importantes; elas são emaranhados mortais e carnais, não unidades finais de entidades. Tipos são importantes; eles também são emaranhados mortais e carnais, não unidades tipológicas de entidades. Indivíduos e tipos em qualquer escala de tempo e espaço não são totalidades autopoiéticas; eles são aberturas e fechamentos dinâmicos e pegajosos num jogo finito, mortal, ontológico, criador de mundo.

Maneiras de viver e morrer são importantes: quais práticas multiespécie de viver e morrer, historicamente situadas, devem florescer? Não há nenhum exterior de onde responder essa questão obrigatória; precisamos dar as melhores respostas que venhamos a saber dar para articular e fazer alguma coisa, sem o truque da certeza de quem finge ser deus. Mundos de espécies companheiras são tartarugas de cima a baixo. Em vez de reduzir tudo a uma sopa de complexidade pós- (ou pré-) moderna na qual tudo acaba sendo permitido, as abordagens de espécies companheiras devem se engajar de fato em 
cosmopolítica, articulando corpos a alguns corpos e não a outros, nutrindo alguns mundos e não outros, e aguentando as consequências mortais. Respeito é respecere - olhar de volta, manter em consideração, compreender que encontrar o olhar do outro é uma condição de também ter um rosto. Tudo isso é o que estou chamando de "partilhar sofrimento". Não se trata de um jogo, mas lembra o que Charis Thompson (2005) chama de coreografia ontológica.

Eu ajo; eu não escondo os cálculos que motivam a ação. Assim, não estou quite com minhas dívidas, que são dívidas mais do que justas. Não estou quite com a respons-abilidade, a capacidade de responder, que exige cálculo, mas não está terminada quando a análise do melhor custo-benefício do dia está feita, e não está terminada quando as melhores regras de bem-estar animal são seguidas ao pé da letra. Os cálculos - razões - são obrigatórios e radicalmente insuficientes para a mundanidade de espécies companheiras. $\mathrm{O}$ espaço aberto por palavras como perdão e maldade permanece, embora eu admita que conotações religiosas ultrapassadas grudam nessas palavras como um mau cheiro, e portanto precisamos também de outras palavras. Temos razões, mas não razões suficientes. A recusa de interrogar as práticas necessárias para obter boas razões (nesse caso, para fazer ciência de laboratório experimental específica) não é apenas estupidez, mas também um crime. Nem os defensores de "o bem humano maior é mais importante do que a dor animal", nem os defensores de "os animais sencientes são sempre fins em si mesmos e então não podem ser usados desta maneira" veem que a pretensão de ter Razão Suficiente é uma perigosa fantasia enraizada nos dualismos e concretudes mal colocadas do humanismo religioso e secular.

Obviamente, tentar imaginar quem fica fora do radar da senciência e portanto é matável, enquanto construímos casas de repouso para macacos, também é uma caricatura daquilo que deve ser feito. Temos a obrigação, pode crer, de tornar as vidas desses macacos de laboratório tão plenas quanto possível (aumente impostos para cobrir os custos!) e de retirá-los das situações nas quais indesculpavelmente os colocamos. As ciências biocomportamentais comparativas avançadas, dentro e fora dos laboratórios, assim como a reflexão e a ação política e ética afetivas, nos dizem que não há quaisquer condições suficientemente boas para continuar permitindo muitos tipos de experiências e práticas de cativeiro de animais, não apenas macacos. Veja-se bem, acho que sabemos disso, pelo menos em grande parte, por causa da pesquisa. Mas, 
repito, esses cálculos - necessários, obrigatórios, explicados em voz alta e em público - não são suficientes.

Agora, como tratar essa respons-abilidade (que é sempre experienciada na companhia de outros significantes, nesse caso, os animais)? Como você diz, Sharon, o problema não reside em Princípios e Universais Éticos, mas em práticas e políticas imaginativas do tipo que rearticula as relações de mentes e corpos, nesse caso as criaturas e seu pessoal de laboratório e os aparatos científicos. Por exemplo, que tal instituir mudanças nas rotinas dos laboratórios de maneira que até os ratos ou camundongos possam aprender como fazer coisas novas e tornar suas vidas mais interessantes. (Um treinador para melhorar as vidas de sujeitos é uma coisa pequena, mas importante.) Afinal de contas, no mundo da biotecnologia, os roedores sofrem o impacto do uso invasivo crescente em todo o mundo. ${ }^{25}$ Além do cuidado à criança humana devido

${ }^{25}$ Para se ter uma ideia desse aumento no uso de roedores, é só observar a importância dos ratos com nocaute de genes. O nome do jogo é genômica comparativa. Vários países têm novos grandes projetos de produzir dezenas de milhares de ratos nocaute, isto é, linhagens de camundongos com genes bloqueados. Por exemplo, o Instituto Nacional de Saúde dos EUA anunciou o Knockout Mouse Project para produzir dez mil novos mutantes; a Europa e o Canadá estão atrás de outros 30 mil. A China pretende produzir cem mil diferentes mutantes em 20 mil linhagens de camundongos, cada uma com um gene nocaute diferente. A revista Science calcula que esse seja o maior esforço de cooperação internacional desde o Projeto Genoma Humano. O objetivo é ter nocautes para cada gene de camundongo e torná-los publicamente disponíveis. Ratos mutantes produzidos em massa são a máquina-ferramenta para estudos comparativos de função genética. Catalogação, distribuição e propriedade intelectual são apenas algumas das questões totalmente difundidas. Ver Grimm (2006). O bem-estar dos ratos jamais é mencionado. Como poderia sê-lo, quando o status deles enquanto animais se perde numa retórica como a seguinte?: "Os projetos nocaute, como um grupo, estão tentando criar algo semelhante à superloja internacional IKEA, onde numa única visita os consumidores podem comprar a preços razoáveis peças de fácil montagem para mobiliar uma casa inteira [...] Alguma montagem seria necessária: transformar aqueles embriões congelados em camundongos vivos [...] Tal recurso estaria muito longe do comércio atual de ratos, que se assemelha mais a comprar móveis dos vizinhos." (Grimm, 2006, p. 1863). Eu não me oponho à pesquisa invasiva com ratos que seja cuidadosamente considerada. Minha questão não é essa, mas sim como entrar de cara limpa nessas práticas, dentro da trama mortal de vir a ser com outros animais. Considero coletivamente psicótico e altamente funcional lidar com retórica e outras práticas de pesquisa como se os camundongos fossem apenas ferramentas ou produtos e não também criaturas companheiras sencientes. É muito difícil se segurar no ambos/e. Não conseguir se segurar no ambos/e significa despencar no abismo intransponível entre a racionalidade instrumental autocomplacente, por um lado, e um discurso de direito à vida quiçá igualmente autocomplacente, por outro lado. O problema para as espécies companheiras, eu afirmo, não é como ficar satisfeito, mas como lidar com a indigestão. O mesmo número da Science, algumas páginas antes da matéria sobre os ratos nocaute, traz um item intitulado "Sinais de empatia em camundongos" (p. 1860) Poderia ser mais apropriado perguntar se muitas pessoas apresentam tais sinais quando lidam com camundongos. Talvez os genes humanos para suportar tais capacidades tenham sido bloqueados por pesquisadores gatos alienígenas em uma era primitiva. Ver também Birke (2003).

Horizontes Antropológicos, Porto Alegre, ano 17, n. 35, p. 27-64, jan./jun. 2011 
pelos laboratórios, eu adoraria ver a criação de oportunidades de trabalho para treinadores de animais e praticantes de enriquecimento ambiental. Imagino o pessoal de laboratório tendo de se submeter a um teste de capacitação em treinamento com métodos positivos e a um teste de ecologia biocomportamental de laboratório para as espécies com as quais trabalham, para manter seus empregos e obter aprovação para suas pesquisas. Os experimentadores teriam de fazer tais testes pelas mesmas razões que os patrões e empregados têm de aprender, hoje em dia, que o assédio sexual é real (mesmo que frequentemente o aparato regulatório pareça ser uma caricatura daquilo que as feministas pretendiam); ou seja, a menos que sejam retreinadas, as pessoas, como os outros animais, continuam vendo e fazendo aquilo que já viam e faziam e isso não é suficiente.

É claro que imaginar que as reformas resolverão o problema é uma falha do pensamento afetivo e efetivo e uma negação de responsabilidade. Novas aberturas aparecerão por causa das mudanças das práticas e o aberto diz respeito à resposta. Acho que, de fato, isso acontece o tempo todo com bons experimentadores e suas criaturas. Na maior parte deste artigo, enfoquei as relações científicas instrumentais, desiguais, entre vertebrados humanos e não humanos com cérebros consideráveis que as pessoas identificam como sendo semelhantes aos delas próprias em aspectos vitais. No entanto, os animais, na sua a grande maioria, não são assim; o cuidado não mimético e a alteridade significante são meu chamariz para tentar pensar e sentir de maneira mais adequada; e o florescimento de um olhar multiespécies exige uma forte sensibilidade não antropomórfica atenta a diferenças irredutíveis.

Em uma banca de doutorado com minha colega Vicky Pearse, zoóloga de invertebrados marinhos, eu aprendi como ela busca maneiras de proporcionar maior conforto aos seus corais no laboratório procurando saber quais os comprimentos de onda e períodos de luz que eles gostam. Obter bons dados é importante para ela, e manter animais felizes também, isto é, o real bem-estar dos animais no laboratório. ${ }^{26}$ Inspirada por Pearse, pedi a alguns de meus

${ }^{26}$ Pearse é pesquisadora no Instituto de Ciências Marinhas da Universidade da Califórnia em Santa Cruz, editora da renomada revista Invertebrate Biology, e coautora do clássico texto Animals without backbones: an introduction to the invertebrates (Buchsbaum et al., 1987). Ver www.iode.org/oceanexpert/ viewMemberRecord.php?\&memberID=1623. Pearse ajuda generosamente os alunos de pós-graduação de História da Consciência em estudos de ciência com os aspectos de zoologia marinha de suas teses. Ver Eva Shawn Hayward (2003). 
amigos biólogos que trabalham com invertebrados que me contassem histórias sobre as práticas de cuidado fundamentais para o trabalho deles como cientistas. Eu escrevi:

Você tem um exemplo a partir de sua própria prática ou de pessoas próximas de como o bem-estar dos animais - sempre importante para bons dados, é claro, mas não apenas para isso - é importante no dia a dia do laboratório? Eu quero argumentar que esse cuidado não é no lugar de experimentos que podem envolver matança e/ou dor, mas é intrínseco ao complexo sentimento de responsabilidade (e parentesco mundano não antropomórfico) que muitos pesquisadores têm por seus animais. Como você faz seus animais felizes no laboratório (e vice-versa)? Como os bons zoólogos aprendem a ver quando os animais não estão prosperando? As histórias interessantes estão mais nos detalhes do que nos grandes princípios!

Michael Hadfield, professor de zoologia na Universidade do Havaí e diretor do Laboratório Marinho de Kewalo (o Centro de Pesquisa em Biociências do Pacífico), respondeu:

Suas perguntas me fazem pensar mais no meu trabalho com os caramujos havaianos de árvore do que os nossos bichinhos no laboratório marinho. Eu tive muito trabalho para proporcionar a esses caramujos em via de extinção ambientes de laboratório tão semelhantes quanto possível a um cenário de campo. Para tanto, compramos "câmaras ambientais" bastante caras nas quais podemos ajustar a duração do dia e os sistemas de temperatura-umidade que mais se aproximam aos dos habitats dos caramujos no campo. Nós tentamos também fornecer um mundo de folhas e o mofo que eles raspam das folhas em abundância. O mais importante é que oferecemos tudo isso em um mundo livre de predadores, para "salvá-los" das espécies exóticas [espécies altamente destrutivas introduzidas no ambiente, como caramujos predadores e ratos] que os estão devorando no alto das montanhas. Eu também acho que os caramujos são lindos e os seus bebês "adoráveis", mas isso não é lá muito científico, certo? Por vários motivos - para não falar do seu status legalmente protegido -, nós fazemos um grande esforço para não machucar nem matar nenhum caramujo no laboratório. Eu realmente quero que essas espécies continuem no mundo, e o que fazemos no laboratório é, neste momento, a única maneira que eu conheço de fazer isto acontecer. Estamos agora cuidando de mais de 1500 caramujos de árvore no laboratório, à custa de muitos gastos e esforço pessoal, com o objetivo de evitar que as extinções sejam ainda maiores do que as que já ocorreram. Isso implica 
principalmente em manter os caramujos tão saudáveis e "naturais" quanto possível ("naturais", porque algum dia eles devem retornar ao campo - e lá sobreviver). Se "mantê-los felizes" é isso, então esta é a força que nos move.

Como vemos (presumindo que somos "bons zoólogos") que nossos animais não estão prosperando? Ah, bem, geralmente é quando eles morrem. Caramujos e lagartas não emitem gritos de dor, nem costumam dar sinais de doença muito antes de morrer. No caso desses caramujos de árvore, eu observo cuidadosamente as tendências demográficas em cada terrário (fazemos o recenseamento deles pelo menos a cada duas semanas) para saber se há nascimentos, se a taxa de mortalidade é maior do que a de natalidade, etc. Ao menor sinal de que alguma coisa está errada, eu imediatamente faço o pessoal do laboratório parar e rever cada etapa do processo de manutenção e cultura. Muitas vezes temos de verificar uma câmara ambiental inteira (mais de dez diferentes terrários, com várias espécies) para ver se há algo errado com o ambiente como um todo. E tomamos providências imediatas para remediar situações, mesmo quando não as compreendemos inteiramente. Por exemplo, recentemente eu cheguei à conclusão que minha equipe de laboratório estava enchendo demais os terrários com galhos folhados de $o h i$ ' $a$ a cada sessão de limpeza e troca de galhos. Eles tinham concluído que, como a comida dos caramujos é o mofo que cresce nas folhas, quanto mais folhas melhor. Eu expliquei que os caramujos precisavam de maior circulação de ar nos terrários e que suas atividades eram fortemente reguladas pela luz, que quase não chegava ao centro dos terrários cheios demais. Então, consertamos aquilo e agora estamos procurando o próximo problema e o "remédio". ${ }^{27}$

Scott Gilbert, em cujo trabalho eu me inspirei constantemente durante muitos anos, também me deu uma história baseada em sua pesquisa experimental, com alunos de graduação da Faculdade de Swarthmore, sobre a origem embrionária do plastrão da tartaruga a partir de células neurais da crista:

Geralmente não permito que meus alunos matem nenhum animal. Esse sempre foi um dos meus trabalhos. Não me importo muito em dissecar embriões de tartaruga extraídos de suas gemas e colocá-los em $4 \%$ de paraformaldeído. Eu, provavelmente, toleraria melhor passar um dia fazendo isso do que despachar uma tartaruga adulta ou um filhote. Eu não conheço nenhuma história tão provocativa quanto a que você mencionou sobre o homem que teve o braço picado por

27 Michael Hadfield, comunicação pessoal (e-mail, 02/08/2006). Sobre a pesquisa de caramujos, ver Hadfield, Holland e Olival (2002). Ver também www.kewalo.hawaii.edu/labs/hadfield/ e http://swww.hawaii.edu/zoology/faculty/hadfield.htm ou http://www.hawaii.edu/eecb/FacultyPgs/michaelhadfield.html.

Horizontes Antropológicos, Porto Alegre, ano 17, n. 35, p. 27-64, jan./jun. 2011 
moscas-tsé-tsés. O fundador deste departamento, Joseph Leidy, era uma pessoa notável e, segundo uma lenda, caminhou de Filadélfia a Swarthmore porque tinha se esquecido de pedir a um aluno para alimentar os sapos e lagartos. ${ }^{28}$

Gosto da linguagem da "política" como ela é usada por Despret, Latour e Stengers, que a meu ver está relacionada a polis e polido: boas maneiras (politesse), que responde a e com alguém. Hadfield, Gilbert e Pearse são “polidos"; são exemplos da prática cosmopolítica biológica que articula corpos a outros corpos com cuidado para que outros significantes possam prosperar. O trabalho deles está imerso nas minúcias diárias de vida e morte para os animais (e os estudantes e pós-doutores) sob seus cuidados e com os quais e dos quais aprendem. Acho arriscado assimilar esse trabalho à categoria da "bioética", mas tampouco estou preparada para entregar a palavra ética ao inimigo. É aquela minha velha recusa a desistir daquilo que muita gente diz que eu não posso ter, como ciborgue, por exemplo. Eu não me esquivo da decisão de matar animais pelas melhores razões que encontro; tampouco me esquivo do que é necessário para formular tais razões. Apenas estou dizendo que isso não encerra a questão; isso abre a questão. Talvez isso seja tudo que o não humanismo significa. Mas nesse pequeno "tudo" reside a permanente recusa de inocência e autocomplacência com nossas razões e o convite a especular, imaginar, sentir, construir algo melhor. Essa é a ideia de mundo na ficção científica que sempre me atraiu. É uma construção real de mundo.

Sem dúvida, Whitehead $(1938,1979,1997)$ nas mãos de Stengers (2002) fala de abstrações como iscas quando nossas abstrações anteriores se desfazem. ${ }^{29}$ Amar nossas abstrações me parece realmente importante; compreender que elas se desfazem mesmo enquanto nós amorosamente as forjamos faz parte de nossa respons-abilidade. As abstrações, nossos melhores cálculos, matemáticas, razões, são construídas a fim de poderem se desfazer para que invenções, especulações e proposições - ideias de mundo - mais ricas e mais responsivas possam ir em frente. Uma proposição whiteheadiana, diz Stengers, é um risco, uma janela para aquilo que ainda não é. Uma proposição é também uma janela para vir a ser com aqueles com quem ainda não estamos. Ponha

28 Scott Gilbert, comunicação pessoal (e-mail, 09/08/2006).

29 Ver também Latour (2003) para a resenha de Penser. 
isso dentro do dilema resultante da matança de organismos experimentais ou animais para carne, e o apelo "ético" ou "político" obrigatório é reimaginar, especular novamente, permanecer aberto, porque nós estamos (moderadamente, se construímos boas abstrações; gravemente, se formos preguiçosos, inábeis ou desonestos) matando alguém, não simplesmente alguma coisa.

Estamos frente a frente, na companhia de outros significantes, espécies companheiras umas das outras. Isso não é romântico ou idealista, mas mundano e se reflete nas pequenas coisas que fazem vidas. Em vez de encerrar a questão dizendo que essa ciência experimental é boa, inclusive a do tipo que mata animais quando necessário e segundo os mais altos padrões que coletivamente sabemos pôr em andamento, nossa dívida está apenas se abrindo para a reconstrução especulativa do mundo e assim para mundos possíveis, materiais, afetivos, práticos na situação detalhada e concreta do aqui, nessa tradição de pesquisa, não em toda parte e o tempo todo. Esse "aqui" pode ser bem grande, até mesmo global, se as abstrações forem realmente bem construídas e cheias de ganchos para agarrar as conexões. Talvez a ideia de mundo da ficção científica - ficção especulativa e fato especulativo - seja a linguagem que necessito em vez de perdão e maldade. Talvez até Baba Joseph e Cixous pensariam assim, mesmo se os carrapatos e as moscas-tsé-tsés provavelmente não. E talvez o melhor de tudo, no laboratório e no campo, caramujos de árvore havaianos possam de fato ter uma chance de viver naturalmente graças aos cuidados não antropomórficos, não miméticos e escrupulosamente detalhados de um zoólogo experimental de invertebrados.

Traduzido do inglês por José Fonseca. Atualização bibliográfica de Lucas Besen.

\section{Referências}

ADAMS, C. J. Neither man nor beast: Feminism and the defense of animals. New York: Continuum, 1995.

ADAMS, C. J.; DONOVAN, J. (Org.). Animals and women: feminist theoretical explorations. Durham: Duke University Press, 1995. 
AGAMBEN, G. Poverty in the world. In: AGAMBEN, G. The open: man and animal. Stanford: Stanford University Press, 2004. p. 49-77.

ANIMAL STUDIES GROUP. Killing animals. Urbana: University of Illinois Press, 2006.

BARAD, K. Meeting the universe halfway: quantum physics and the entanglement of matter and meaning. Durham: Duke University Press, 2007.

BIRKE, L. Feminism, animals, and science: the naming of the shrew. Buckingham: Open University Press, 1994.

BIRKE, L, Who - or what - is the laboratory rat and mouse? Society and Animals, v. 11, n. 3, p. 207-224, 2003.

BRYLD, M.; LYKKE, N. Cosmodolphins: feminist cultural studies of technology, animals, and the sacred. Londres: Zed Books, 2000.

BUCHSBAUM, R. et al. Animals without backbones: an introduction to the invertebrates. $3^{\text {rd }}$ ed. Chicago: University of Chicago Press, 1987.

CIXOUS, H. Stigmata, or Job the dog. In: CIXOUS, H. Stigmata: escaping text. New York: Routledge, 1998. p. 243-261.

COE, S. Pit's letter. New York: Four Walls Eight Windows, 2000.

CRIST, E. Images of animals: anthropomorphism and animal mind. Philadelphia: Temple University Press, 1999.

COETZEE, J. M. Disgrace. New York: Viking, 1999.

COETZEE, J. M. The lives of animals. Princeton: Princeton University Press, 2001.

COETZEE, J. M. Elizabeth Costello. New York: Viking, 2003.

COGHLAN, A. Animal welfare: see things from their perspective. New Scientist, n. 2570, p. 6-7, Sept. 2006.

DERRIDA, J. The animal that therefore i am (more to follow). Critical Inquiry, v. 28, n. 2, p. 369-418, Winter 2002. 
DERRIDA, J. And say the animal responded? In: WOLFE, C. (Org.). Zoontologies: the question of the animal. Minneapolis: University of Minnesota Press, 2003. p. 121-146.

DERRIDA, J.; NANCY, J.-L. "Eating well”, or the calculation of the subject: an interview with Jacques Derrida. In: CADAVA, E.; CONNOR, P.; NANCY, J.-L. (Org.). Who comes after the subject? New York: Routledge, 1991. p. 96-119.

DESPRET, V. Sheep do have opinions. In: LATOUR, B.; WEIBEL, P. (Ed.). Making things public: atmospheres of democracy. Cambridge: MIT Press, 2006. p. 360-370.

DESPRET, V. The body we care for: figures of anthropo-zoo-genesis. Body\& Society, v. 10, n. 2-3, p. 111-134, June 2004.

FARMER, N. A girl named Disaster. New York: Orchard Books, 1996.

FUDGE, E. Animals. London: Reaktion Books, 2002.

GAARD, G. (Org.). Ecofeminism: women, animals, nature. Philadelphia: Temple University Press, 1993.

GRIMM, D. A mouse for every gene. Science, v. 312, n. 5782, p. 1862-1866, June 2006.

HADFIELD, M. G.; HOLLAND, B. S.; OLIVAL, K. J. Contributions of ex situ propagation and molecular genetics to conservation of Hawaiian tree snails. In: GORDON, M.; BARTOL, S. (Org.). Experimental approaches to conservation biology. Berkeley: University of California Press, 2002. p. 16-34.

HARAWAY,D.Modest_Witness@Second_Millennium.FemaleMan_Meets_ OncoMouse: Feminism and Technoscience. New York: Routledge, 1997.

HARAWAY, D. When species meet. Minneapolis: University of Minnesota Press, 2008.

HARDING, S. Get religion. In: COLLOQUIUM SERIES, 2006, Santa Cruz. 
HARTSOCK, N. The feminist standpoint: developing the ground for a specifically feminist historical materialism. In: HARDING, S.; HINTIKKA, M. (Org.). Discovering reality. Dordrecht: Reidel, 1983. p. 283-310.

HAYWARD, E. S. Envisioning invertebrates: immersion, inhabitation, and intimacy as modes of encounter in Marine TechnoArt. Monografia. Departamento de História da Consciência, Universidade da Califórnia, Santa Cruz, 2003.

HERZIG, R. M. Suffering for science: reason and sacrifice in modern America. New Brunswick: Rutgers Univesity Press, 2005.

HOGAN, L. Power. New York: W. W. Norton, 1998.

HUBRECHT, R. Comfortable quarters for dogs in research institutions. In: REINHARDT, V. Comfortable quarters for laboratory animals. Washington: Animal Welfare Institute, 2002. p. 56-64. Disponível em: <http://www. awionline.org/www.awionline.org/pubs/cq02/Cq-dogs.html>. Acesso em: 24 fev. 2011.

INSIDE Huntingdon Life Sciences. Stop Huntingdon Animal Cruelty, [s.d.]. Disponível em: <http://www.shac.net/HLS/exposed/inside_hls/Inside_HLS. pdf $>$. Acesso em: 24 fev. 2011.

KUZNIAR, A. Melancholia's dog. Chicago: University of Chicago Press, 2006.

LATOUR, B. What is given in experience?: a review of Isabelle Stengers Penser avec Whitehead: Une libre et sauvage création de concepts. 2003. Disponível em: <http://www.bruno-latour.fr/articles/article/93-STENGERS. html>. Acesso em: 24 fev. 2011.

LATOUR, B. Politics of nature: how to bring the sciences into democracy. Cambridge: Harvard University Press, 2004.

LE GUIN, U. Buffalo gals and other animal presences. New York: New American Library, 1998.

MACPHERSON, C. B. The political theory of possessive individualism. London: Oxford University Press, 1962. 
PEMBERTON, S. Canine technologies, model patients: the historical production of hemophiliac dogs in American biomedicine. In: SCHREPFER, S.; SCRANTON, P.(Org.). Industrializing organisms: introducing evolutionary history. New York: Routledge, 2003. p. 191-213.

PLUMWOOD, V. Feminism and the mastery of nature. London: Routledge, 1993.

PUIG DE LA BELLACASA, M. Thinking with care. In: GHAMARITABRIZI, S. (Ed.). Thinking with Donna Haraway. Boston: MIT Press, 2008.

RADER, K. Making mice: standardizing animals for biomedical research, 1900-1955. Princeton: Princeton University Press, 2004.

SCHREPFER, S.; SCRANTON, P. (Org.). Industrializing organisms: introducing evolutionary history. New York: Routledge, 2003.

SMITH, B. H. Animal relatives, difficult relations. Differences, v. 15, n. 1, p. 1-23, Spring 2004.

SMUTS, B. Encounters with animal minds. Journal of Consciousness Studies, v. 8, n. 5-7, p. 293-309, May/July 2001a.

SMUTS, B. Reflections. In: COETZEE, J. M. The lives of animals. Princeton: Princeton University Press, 2001b. p. 107-120.

STENGERS, I. Penser avec Whitehead. Paris: Gallimard, 2002.

STENGERS, I. Cosmopolitiques I. Paris: La Découverte, 2003a.

STENGERS, I. Cosmopolitiques II. Paris: La Découverte, $2003 \mathrm{~b}$.

STENGERS, I. The cosmopolitical proposal. In: LATOUR, B.; WEIBEL, P. (Org.). Making things public: atmospheres of democracy. Cambridge: MIT Press, 2005. p. 994-1003.

SUTHERLAND, A. Kicked, bitten, and scratched: life and lessons at the world's premier school for exotic animal trainers. New York: Viking, 2006.

THOMPSON, C. Making parents. Cambridge: MIT Press, 2005. 
WALKER, A. Am I blue? In: WALKER, A. Living by the word. New York: Harcourt Brace, 1987. p. 3-8.

WHITEHEAD, A. N. Modes of thought. New York: Macmillan, 1938.

WHITEHEAD, A. N. Process and reality: (Gifford Lectures delivered in the University of Edinburgh during the session 1927-28). New York: Free Press, 1979.

WHITEHEAD, A. N. Science and the modern world. New York: Free Press, 1997.

WOLFE, C. Animal rites: American culture, the discourse of species, and posthumanist theory. Chicago: University of Chicago Press, 2003.

WOLFE, C. Exposures. In: CAVELL, S. et al. Philosophy and animal life. New York: Columbia University Press, 2008. p. 1-41.

WOOD, D. Comment ne pas manger - deconstruction and humanism. In: STEEVES, H. Peter. Animal others: on ethics, ontology and animal life. Albany: State University of New York Press, 1999. p. 15-35.

Recebido em: 31/07/2010

Aprovado em: 15/08/2010 